\title{
Effect of Salicylic Acid and Calcium Nitrate Spraying on Qualitative Properties and Storability of Fresh Jujube Fruit (Ziziphus jujube Mill.)
}

\author{
Hadi ZERAATGAR ${ }^{1}$, Gholam Hossain DAVARYNEJAD ${ }^{2 *}$, \\ Farid MORADINEZHAD ${ }^{3}$, Bahram ABEDI ${ }^{4}$
}

\author{
${ }^{1}$ Ferdowsi University of Mashhad, Faculty of Horticultural Science, Mashhad, Iran / South Khorasan Agricultural and Natural Resources \\ Research and Education Center, AREEO,Birjand, Iran; zeraatgarh@yahoo.com \\ ${ }^{2}$ Ferdowsi University of Mashhad, Faculty of Horticultural Science, Mashhad, Iran; davarynej@um.ac.ir ('correspondingauthor) \\ ${ }^{3}$ Birjand University, Faculty of Horticultural Science,Birjand, Iran; fmoradinezhad@birjand.ac.ir \\ ${ }^{4}$ Ferdowsi University of Mashbad, Faculty of Horticultural Science, Mashhad, Iran; abedy@um.ac.ir
}

\begin{abstract}
Chinese jujube is among the important medicinal plants grown in Iran. Its valuable fruit have a short post-harvest life. Delaying of quality reduction for few days can help maintaining the shelf life of fresh jujube fruit. The current study was conducted to investigate the possible effects of pre-harvest foliar application of salicylic acid (0,2 and $4 \mathrm{mM})$ and calcium nitrate $(0,1$ and $2 \%)$ on physico-chemical characteristics and shelf life of fresh jujube fruit during storage at 10-days intervals, for 40 days. Results indicated that salicylic acid and calcium nitrate played an important role in maintaining and extending post-harvest quality of fresh jujube fruit, as both substances increased fruit firmness, titrable acidity, total phenolic content, antioxidant activity, ascorbic acid and catalase enzyme, but reducing total soluble solids. The highest total phenolic content $(2.38 \mu \mathrm{g}$ gallic acid/gFW), antioxidant activity $(76.73 \mathrm{mmol}$ Trolox/g), ascorbic acid $(222.4 \mathrm{mg} / 100 \mathrm{~g}$ FW) and catalase enzyme (16.67 U. mg ${ }^{-1}$ protein), as well as the lowest total soluble solids content $(23.11 \%)$ were observed when salicylic acid 4 $\mathrm{mM}$ was used. Furthermore, maximum fruit firmness $(4.22 \mathrm{~N})$ was obtained in the treatment containing calcium nitrate $2 \%$. Treatment containing salicylic acid $2 \mathrm{mM}$ and calcium nitrate $2 \%$ had the highest amount of titrable acidity TA (0.45\%). Based on the results, reducing trends of some components like ascorbic acid, antioxidant and phenol, were very fast, even when using salicylic acid and calcium nitrate; their application could cause a delay in these processes, but the quality reduction found could not be compensated. In other characteristics that had a slower quality reducing trend, the application of salicylic acid and calcium nitrate could cause at least a 10-day delay in the reduction of the amounts of these attributes.
\end{abstract}

Keywords: agro-chemical substance, cell wall rigidity, fruit texture, ripening process, storage life

\section{Introduction}

Chinese jujube (Ziziphus jujuba Mill.), belonging to Rhamnaceae family, has been cultivated in China, the Mediterranean region, southern and eastern parts of Asia, some regions of North Italy, west and south of Turkey (Kirkbride et al., 2006; Ercisli et al., 2007; Ecevit et al., 2008; Gao et al., 2013) and Iran, especially in Southern Khorasan province from long ago.

Being one of the important medicinal plants, Jujube fruit is grown in arid and semi-arid regions, in temperate and subtropical regions (Liu and Zhao, 2009). It is one of the world's most nutritious plants, rich in vitamin $\mathrm{C}$, minerals and amino acids (Li et al., 2007; Boora and Bal, 2008) and contains various types of bioactive substances such as triterpenic acid, volatileoil, glycosides, saponins and flavonoids that have wide pharmacological effects on humans (Zhao et al., 2008; Ji et al., 2017). Moreover, it is used as table fruit, dry fruit and medicinal plant.

This valuable fruit has a short post-harvest life, characterized by softness and decrease in soluble solids content due to senescence, flesh browning, quality deterioration (Jiang et al., 2004) and fungal diseases (Tian et al., 2005; Cao et al., 2013). Therefore, any efforts that could be made to produce fruits with high quality parameters such as firmness, color intensity, fruit uniformity and increase of ascorbic acid, total phenolic and total antioxidant activity at harvest and during marketing, would be very important for the jujube growers in order to obtain higher return of resources.

The application of agro-chemical substances is considered as one of the most innovative methods to extend the 
commercial storage life of vegetables and fruits. Accordingly, some efforts have been made by using particular agro-chemical substances to delay ripening, decrease losses, increase and maintain fruit quality by reducing the speed of metabolic activities at harvest or during storage (Shafiee et al., 2010). Sudha et al. (2007) reported that some chemicals could cause an increase in sapota fruit shelf-life and maintain its market ability for a longer term by arresting the growth and spread of micro-organisms. According to John (1987), calcium improves rigidity of cell walls and obstructs enzymes such as poly galacturonase from reaching their active sites, consequently retarding tissue softening and delaying ripening. The movement of calcium in plants is very slow because part of the calcium existing in plants bounded as a building material and other part is in outer surface of the plasma membrane and cell wall as exchangeable form. On the other hand, a large amount of calcium is enclosed in vacuoles and that is the reason for its very low concentration in the cytosol; therefore calcium cannot move in the phloem vessels through symplast and only moves through xylem vessels (Marschner, 2011).

Calcium application maintains cell turgor, membrane integrity and tissue firmness, and delays membrane lipid catabolism, which extend storage life of fresh fruits (Rizk-Alla and Meshreki, 2006). Moreover, calcium existing in fruit tissues usually prevents post-harvest disorders, retards fruit ripening and decreases fruit weight loss and decay (Lara $e t$ al., 2004; Hernandez-Munoz et al., 2006). Calcium nitrate sprayed on jujube increased fruit weight and reduced cracking, sugar content and total acidity (Hu et al., 2013). The use of calcium compounds on ber - Indian jujube also reduced the brown spots and increased the amount of calcium in fruit texture (Shamili and Hajiani, 2012).

Salicylic acid is also an endogenous growth regulator with phenolic nature, which participates in the regulation of several physiological processes in plants, such as stomata closure, ion uptake, inhibition of ethylene biosynthesis and transpiration (Khan et al., 2003). It is used as a food additive in handling harvested fruits to delay ripening processes of some fruits as well as enhancing the tolerance of fruits against pathogens, particularly at the early maturity stage (Cao et al., 2006). Furthermore, salicylic acid was reported to reduce fruit weight loss and softening (Shafiee et al., 2010).

Some studies showed that storage at low temperature effectively delayed fruit ripening and extended post-harvest life of fresh jujube, but the beneficial effects may be limited by undesirable physico-chemical changes (Crisosto et al., 2004; Manganaris et al., 2007). The consequences of these changes were the acceleration of quality loss and reduction in consumer acceptability. Thus, there is a need for retarding or inhibiting the physico-chemical changes, as well as improving fruit storability. It was the aim of the present study to evaluate the effects of salicylic acid and calcium nitrate spray on some qualitative characteristics of jujube.

\section{Materials and Methods}

Plant material preparation, treatments and storage conditions

The jujube trees were selected from a commercial orchard established in Agricultural Research Center of Southern Khorasan province (Birjand), Iran. All trees were similar regarding age ( 15 years) and orchard management.
All treatments were sprayed with calcium nitrate $(0,1$ and $2 \%)$ and salicylic acid (0,2 and $4 \mathrm{mM})$ as preharvest treatments. three times [in colour change stage (August 5 - August 22) from green to white till a week before harvesting].

The fruits were harvested at crisp mature stage and transferred to the laboratory; then, uniform fruits in size and free from diseases were selected, packed in perforated polyethylene with a thickness of 30 microns, and kept at $4 \pm 1^{\circ} \mathrm{C}$ and $85 \%$ to 90\% R.H in the refrigerator (Wu et al., 2012). The different measurements were performed during storage (0-10-20-30-40) days after harvesting.

\section{Determination of quality attributes}

A hand-held refractometer (Atago, Tokyo, Japan) was used to measure total soluble solids (TSS). Titrable acidity (TA) was specified by titration with $0.1 \mathrm{~N} \mathrm{NaOH}$ to an endpoint of $\mathrm{pH}$ 8.1 and expressed as percentage of citric acid (Gao et al., 2011). Fruit firmness $(\mathrm{N})$ was measured on ten fruits from each sample using a TA-XT2i texture analyzer (Stable Micro Systems Ltd, Godalming, UK) fitted with a $2 \mathrm{~mm}$ diameter probe operated at a speed of $1 \mathrm{~mm} \mathrm{~s}^{-1}$.

\section{Determination of ascorbic acid content}

Ascorbic acid content was quantified in accordance with the dinitrophenyl hydrazine (DNPH) method, modified by Nunes et al. (1995). Freeze dried powder $(0.2 \mathrm{~g})$ was homogenized in mortar pestle, with $20 \mathrm{~mL}$ of a mixture of $6 \%$ (w/v) metaphosphoric acid in $2 \mathrm{~mol} / \mathrm{L}$ acetic acid. The mixture was centrifuged at $17,600 \mathrm{~g}$ for $15 \mathrm{~min}$ at $4{ }^{\circ} \mathrm{C}$. The supernatant was filtered through Whatman filter paper (no.1). An aliquot of 0.05 $\mathrm{mL}$ of $0.2 \%$ (w/v) 2,6-dichlorophenol indophenols (DCPIP) was added to $1 \mathrm{~mL}$ of the supernatant and incubated at room temperature for $1 \mathrm{~h}$. Thiourea solution $(2 \%, \mathrm{w} / \mathrm{v})$ in $5 \%$ metaphosphoric (w/v) acid and $0.5 \mathrm{~mL}$ of $2 \%(\mathrm{w} / \mathrm{v}) \mathrm{DNPH}$ in $4.5 \mathrm{~mol} / \mathrm{L}$ sulphuric acid were added and the solution was incubated at $60^{\circ} \mathrm{C}$ for $3 \mathrm{~h}$. Tubes were placed in an ice bath and $2.5 \mathrm{~mL}$ of ice cold $90 \%$ sulphuric acid was slowly added. Tubes were vortexed and total ascorbic acid was measured by absorbance at $540 \mathrm{~nm}$ by spectrophotometry. A standard curve of ascorbic acid was used to calculate the concentration and results were reported as $\mathrm{mg} / 100 \mathrm{gFW}$.

\section{Determination of totalphenolic contents (TPH)}

The overall phenolic content was determined by using the method described by Slinkard and Singleton (1977). The reaction began when $1 \mathrm{~mL}$ of the supernatant was added into a solution of $1 \mathrm{~mL} 50 \%(\mathrm{v} / \mathrm{v})$ Folin-Ciocalteu reagent solution and $2 \mathrm{~mL}$ saturated $\mathrm{Na}_{2} \mathrm{CO}_{3}$ solution. The mixture was left at room temperature for $30 \mathrm{~min}$. The absorbance was recorded at 750 $\mathrm{nm}$. The total phenolic content was expressed as microgram gallic acid per gram fresh weight.

\section{Determination of antioxidant activity (free radical scavenging activity)}

DPPH assay was performed on the basis of the measurement of the scavenging ability of antioxidants towards the stable DPPH radical (Brand-Williams et al., 1995). A $3.9 \mathrm{~mL}$ aliquot of a $0.0634 \mathrm{mM}$ of DPPH solution, in methanol (95\%), was added to $0.1 \mathrm{~mL}$ of each extract and shaken vigorously. Change in the absorbance of the sample extract was measured at $515 \mathrm{~nm}$ for $30 \mathrm{~min}$ until the absorbance reached a steady state. 
140

The percentage inhibition of DPPH of the test sample and known solutions of Trolox were calculated by the following formula: Inhibition $(\%)=(\mathrm{A} 0-\mathrm{A}) / \mathrm{A} 0 \times 100$, where 'A0' was the beginning absorbance at $515 \mathrm{~nm}$ obtained by measuring the same volume of solvent, and 'A' was the final absorbance of the sample extract at $515 \mathrm{~nm}$. Methanol (95\%) was used as a blank. Results were reported as mmol Trolox/g.

\section{Assay for enzyme activity}

Catalase (CAT) was assayed by using the method of Wang and Tian (2005). Catalase was extracted by using $50 \mathrm{mmol} / \mathrm{L}$ sodium phosphate buffer $(\mathrm{pH} 7.0)$. The reaction mixture included $2 \mathrm{ml}$ sodium phosphate buffer $(50 \mathrm{mmol} / \mathrm{L}, \mathrm{pH} 7.0)$, $0.5 \mathrm{~mL} \mathrm{H} \mathrm{O}_{2}$ (40 mmol/L) and $0.5 \mathrm{~mL}$ enzyme. The decomposition of $\mathrm{H}_{2} \mathrm{O}_{2}$ was measured by the reduction in absorbance at $240 \mathrm{~nm}$.

\section{Statistical analysis}

The experiment was performed in a factorial split-plot based on randomized complete block design with three replications. Data were analyzed by using SAS statistical software[version 6, 2005], and means comparison was performed by using Duncan's multiple range test. Differences at $P<0.05$ were considered as significant.

\section{Results and Discussion}

\section{Total soluble solids (TSS)}

Increase in shelf life duration led to the increase in TSS, so that the highest and the lowest amounts of TSS were obtained at 40 th day $(26.92 \%)$ and zero until the 20th day (22.48$22.63 \%$ ), respectively (Table 1 ). Kokabi and Tabatabai (2011) have been reported that an increase in TSS during storage is due to the increase in invertase enzyme that causes a change in sucrose. The reduction in fruit water content and conversion of cell wall components such as starch, protein, pectin and hemicelluloses into simple soluble sugars during storage are responsible for the increase in TSS content. Furthermore, increase in soluble solids and soluble sugar during the period of fruit ripening may be due to the activity of sucrose-phosphate synthase enzyme (SPS), which is an important enzyme in the biosynthesis of sugars (Hubbard et al., 1991).
Enhancement of salicylic acid concentration caused a significant reduction in TSS, so that the highest and the lowest contents were observed in control $(25.76 \%)$ and concentration of $4 \mathrm{mM}$ (23.11\%), respectively (Table 1 and Fig. 1). The reduction found in TSS is in agreement with the data obtained in fresh jujube and palm (Al-Obeed, 2010, 2012). SA reduces enzyme activity of sucrose-phosphate synthase, and therefore reduces ethylene production and sugar synthesis (Aghdam $e t$ al., 2010).

\section{Titratable acidity $(T A)$}

Based on the data obtained, enhancement in the duration of shelf life led to the reduction of TA. The highest value of TA was obtained at day zero $(0.55 \%)$, while the lowest rate was seen at day 40th of shelf life (Table 1). TA is directly related to the concentration of dominant organic acid, which is an important parameter in maintaining fruit quality. Since organic acids are used as substrates for respiration in enzymatic reactions, it is expected that TA decreases during postharvest (Shokrollahfam et al., 2012). Organic acids are energy sources that are utilized in fruit ripening phase when metabolism increases (Aguayoa et al., 2006).

As the results showed, increase in salicylic acid concentration significantly increase TA, so that the highest and

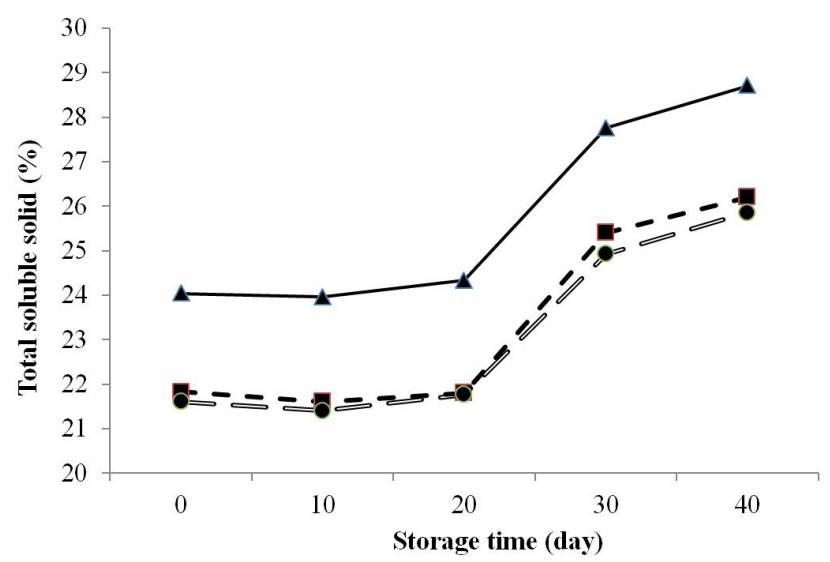

Fig. 1. Effect of salicylic acid on total soluble solid of jujube fruits; ( $\Delta$ ) Control; (•) Salicylic acid $2 \mathrm{mM}$; (•) Salicylic acid $4 \mathrm{mM}$

Table 1: The results of the main treatments and sub effects comparison on the mean of investigated traits

\begin{tabular}{|c|c|c|c|c|c|c|c|}
\hline Treatments & $\begin{array}{l}\text { TSS } \\
(\%)\end{array}$ & $\begin{array}{l}\text { TA } \\
(\%)\end{array}$ & $\begin{array}{l}\text { Fruit } \\
\text { firmness } \\
(\mathrm{N})\end{array}$ & $\begin{array}{c}\text { Ascorbic } \\
\text { acid } \\
(\mathrm{mg} / 100 \mathrm{~g} \mathrm{FW})\end{array}$ & $\begin{array}{l}\text { Total phenolic } \\
\text { content } \\
(\mu \mathrm{g} \text { gallic acid } / \mathrm{g} \\
\text { FW) }\end{array}$ & $\begin{array}{c}\text { Antioxidant } \\
\text { activity } \\
\text { (mmol } \\
\text { Trolox/g) }\end{array}$ & $\begin{array}{l}\text { Catalase } \\
\text { activity } \\
\text { (U.mg }{ }^{-1} \\
\text { protein) }\end{array}$ \\
\hline \multicolumn{8}{|c|}{ Salicylic acid (mM) } \\
\hline 0 & $25.76 \mathrm{a}$ & $0.39 \mathrm{~b}$ & $3.60 \mathrm{~b}$ & $160.93 \mathrm{c}$ & $1.91 \mathrm{~b}$ & $65.93 c$ & $14.33 \mathrm{~b}$ \\
\hline 2 & $23.36 \mathrm{~b}$ & $0.45 \mathrm{a}$ & $4.08 \mathrm{a}$ & $187.33 \mathrm{~b}$ & $2.20 \mathrm{a}$ & $72.93 \mathrm{~b}$ & $15.95 \mathrm{a}$ \\
\hline 4 & $23.11 \mathrm{~b}$ & $0.43 \mathrm{a}$ & $4.06 \mathrm{a}$ & $222.40 \mathrm{a}$ & $2.38 \mathrm{a}$ & $76.73 \mathrm{a}$ & $16.67 \mathrm{a}$ \\
\hline \multicolumn{8}{|c|}{ Calcium nitrate (\%) } \\
\hline 0 & $23.008 \mathrm{a}$ & $0.38 \mathrm{~b}$ & $3.7 \mathrm{~b}$ & $175.86 \mathrm{~b}$ & $1.99 \mathrm{~b}$ & $67.26 \mathrm{~b}$ & $14.70 \mathrm{~b}$ \\
\hline 1 & $24.71 \mathrm{a}$ & $0.44 \mathrm{a}$ & $3.82 \mathrm{~b}$ & $194.33 \mathrm{a}$ & $2.32 \mathrm{a}$ & $73.20 \mathrm{a}$ & $15.96 \mathrm{a}$ \\
\hline 2 & $24.52 \mathrm{a}$ & $0.45 \mathrm{a}$ & $4.22 \mathrm{a}$ & $200.46 \mathrm{a}$ & $2.18 \mathrm{ab}$ & $75.13 \mathrm{a}$ & $16.30 \mathrm{a}$ \\
\hline \multicolumn{8}{|l|}{ Storage (day) } \\
\hline 0 & $22.48 \mathrm{~b}$ & $0.55 \mathrm{a}$ & $4.95 \mathrm{a}$ & $379.33 \mathrm{a}$ & $3.21 \mathrm{a}$ & $97.77 \mathrm{a}$ & $16.38 \mathrm{ab}$ \\
\hline 10 & $22.32 \mathrm{~b}$ & $0.48 \mathrm{~b}$ & $4.46 \mathrm{~b}$ & $248.00 \mathrm{~b}$ & $2.40 \mathrm{~b}$ & $81.44 \mathrm{~b}$ & $17.57 \mathrm{a}$ \\
\hline 20 & $22.63 \mathrm{~b}$ & $0.41 \mathrm{c}$ & $4.03 \mathrm{c}$ & $123.89 \mathrm{c}$ & $2.005 c$ & $69.88 \mathrm{c}$ & $14.46 \mathrm{ab}$ \\
\hline 30 & $26.03 \mathrm{~b}$ & $0.36 \mathrm{~d}$ & $3.21 \mathrm{~d}$ & $102.89 \mathrm{~d}$ & $1.71 \mathrm{~cd}$ & $57.33 \mathrm{~d}$ & $14.91 \mathrm{~b}$ \\
\hline 40 & $26.92 \mathrm{a}$ & $0.32 \mathrm{~d}$ & $2.93 \mathrm{~d}$ & $89.00 \mathrm{~d}$ & $1.48 \mathrm{~d}$ & $52.88 \mathrm{~d}$ & $12.94 \mathrm{c}$ \\
\hline
\end{tabular}


the lowest contents of TA were observed in $2 \mathrm{mM}(0.45 \%)$ and control (0.39\%), respectively (Table 1 and Fig. $2 \mathrm{~A}$ ). Shokrollahfam et al. (2012) reported that any treatments causing a delay in the metabolism and senescence can reduce the rate of TA change during storage. Since the role of salicylic acid has been proved to be delaying fruit ripening and reducing ethylene production and respiration rate, it can decrease the rate of change in TA during shelf life (Han and Li, 1997; Srivastava and Dwivedi, 2000). Sayyari et al. (2009) suggested that application of salicylic acid at the concentration of $4.1 \mathrm{mM}$ in pomegranate (Malas-Saveh) increased TA. Moreover, AlObeed (2010) stated that the application of salicylic acid on palm increased TA. Reynolds and Dweck (1999) also reported that salicylic acid delayed climacteric peak and respiration rate in banana, peach, kiwi and apple.

Results in Table 1 and Fig. 2B showed that TA increased by the application of calcium nitrate. As it can be seen, the highest amount of TA was due to the treatment of calcium nitrate $2 \%$ $(0.45 \%)$, whereas the lowest rate was seen in control $(0.38 \%)$. Shokrollahfam et al. (2012) reported that calcium compounds decreased TA by expanding strong bands in the cell walls. Besides, Al-Obeed (2012) obtained similar results on jujube fruit. This effect can be explained by the formation of cross links between the carboxyl groups of polyuronide chains found in the middle lamella of the cell wall. Calcium decreases the rate of senescence during commercial and retail fruit storage, with no negative effect on consumer acceptance (Lester and Grusak, 2004).

\section{Flesh firmness}

A significant reducing trend was found regarding flesh firmness after harvest, as analysis of data indicated in Table 1. The lowest firmness was observed at 30- and 40-day intervals (Table 1). Fruit texture is often the first of many quality attributes judged by the consumer, and excessive softening is a major factor limiting jujube shelf life. In climacteric fruits softening or reducing fruit texture firmness during storage is the result of the activation of cell wall degrading enzymes such as pectin, methylesterase, polygalacturonase, catalase and cellulase by ethylene (Fischer and Bennett, 1991; Prasanna et al., 2007).

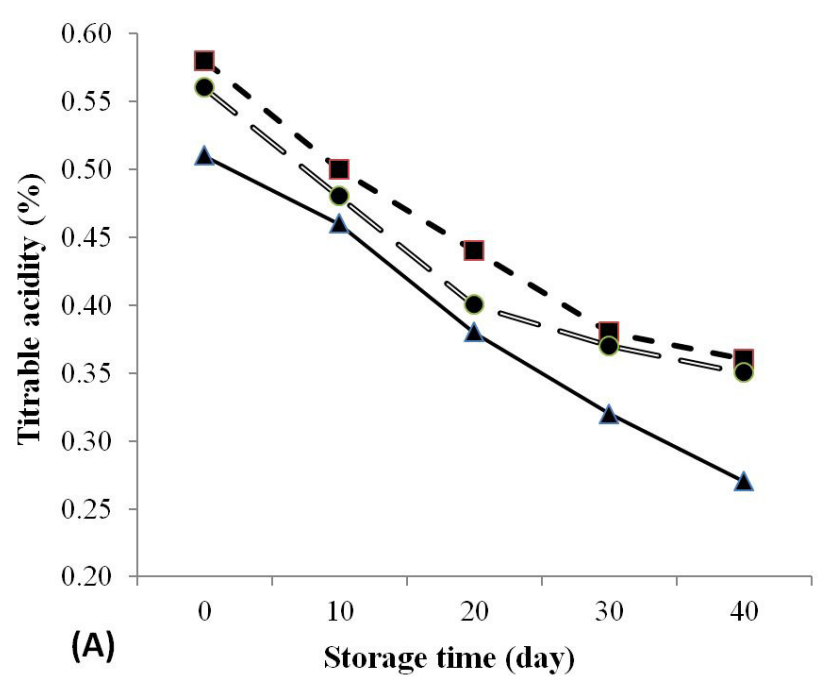

Flesh firmness, as the results showed in Table 1 and Fig. 3 A, was significantly increased as the concentration of salicylic acid enhanced, so that the highest value of firmness was observed in salicylic acid sprayed at concentrations of 2 and 4 $\mathrm{mM}(4.08$ and $4.06 \mathrm{~N}$ ) and the lowest rate was observed in control (3.6 N). Recently, salicylic acid has been proposed as a new kind of plant hormone that led to the higher firmness of fruits and lower fruit chilling injury and decay incidences (Rao et al., 2011). Leslie and Romarini (1988) stated that salicylic acid as a simple phenolic compound maintains firmness by regulating the expression of genes involved in ACC synthase and ACC oxidase enzyme, and reducing ethylene production and cell wall degrading enzymes such as polygalacturonase, cellulase and pectinase (Shafiee et al., 2010). Zhang et al. (2003) reported that salicylic acid affected cell walls and caused fruit to be stronger.

The results obtained on the effect of calcium nitrate application showed that treatment of calcium nitrate produced fruits with higher firmness compared with control and other treatments (Table 1 and Fig. 3 B). Calcium compounds are applied on harvested fruits for the maintenance of quality, prevention of softening and reduction of rottenness rate (Chen et al., 2011). Furthermore, application of calcium maintains cell turgor, membrane integrity and tissue firmness, and delays membrane lipid catabolism, so, it extends the storage life of fresh fruits (Rizk-Alla and Meshreki, 2006). Calcium bands as pectate in the cell walls and tissues are necessary for texture strength. Soft fruit during storage may be dependent on the amount of calcium binding in the cell wall. Calcium ions are linked with phosphate, carboxyl groups, phospholipids and proteins of cell membrane surface, and increase the cell membrane stability (Viccente et al., 2005). In addition, calcium protects cell walls against degrading enzymes (Manganarys et al., 2007). Addition of calcium improves rigidity of cell wall and prevents enzymes such as polygalacturonase from reaching their active sites (John, 1987), therefore increasing firmness, retarding tissue softening and prolonging harvest season (Cheour et al., 1991; Marzouk and Kassem, 2011). This effect can be explained by the formation of cross links between the carboxyl groups of polyuronide chains found in the middle lamella of the cell wall. It reduces the rate of senescence during

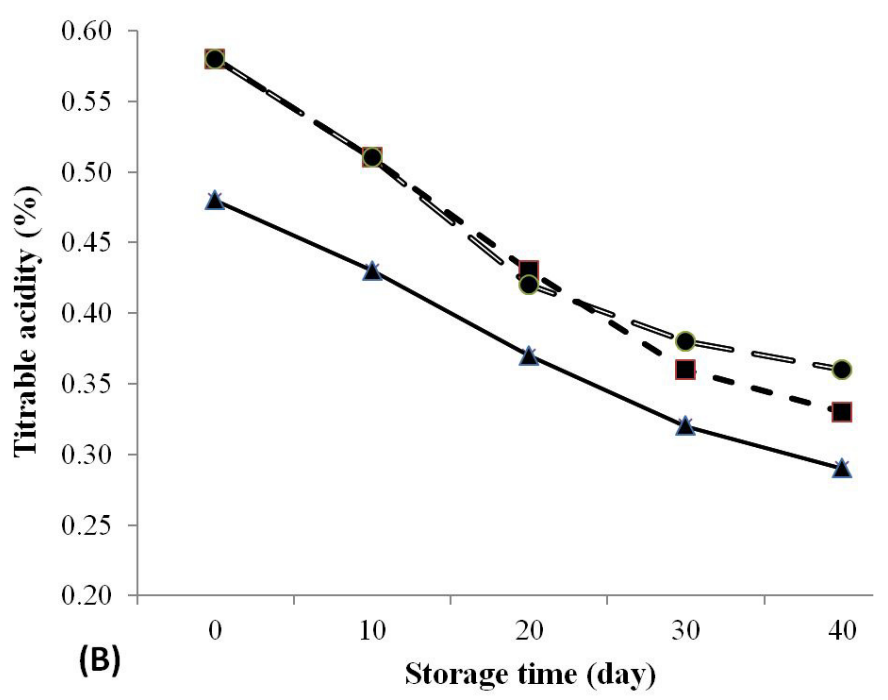

Fig. 2. Effect of salicylic acid and calcium nitrate on titrable acidity of jujube fruits; (A) Salicylic acid: ( $\Delta$ ) Control; (•) Salicylic acid $2 \mathrm{Mm}$; $\bullet$ Salicylic acid $4 \mathrm{mM}(\mathrm{B})$ Calcium nitrate: $(\boldsymbol{\Delta})$ Control; (•)Calcium nitrate $1 \%$; $(\bullet)$ Calcium nitrate $2 \%$ 
142

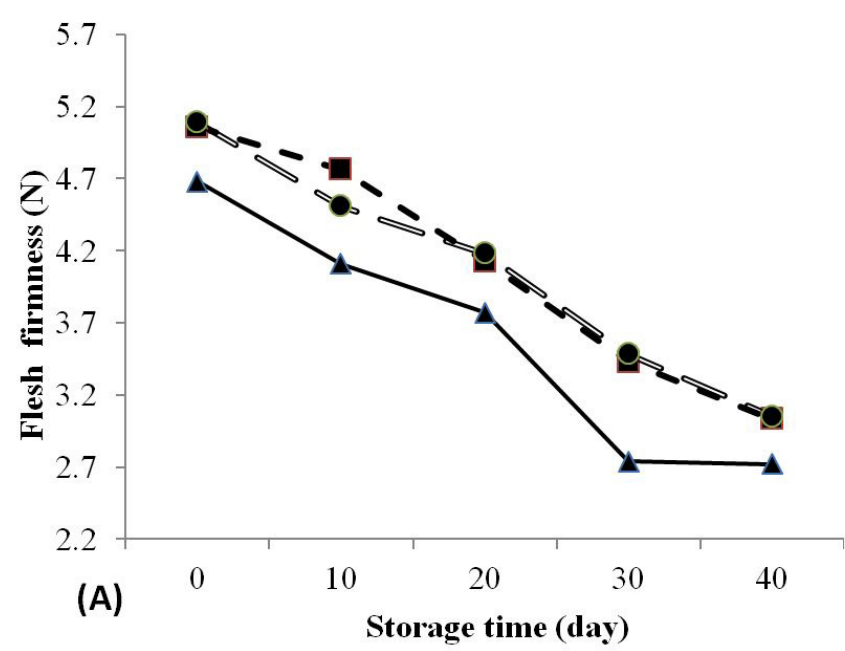

commercial and retail storage of fruit, with no undesirable effect on consumer acceptance (Lester and Grusak, 2004). Moreover, Serrano et al. (2004) showed that plums treated with calcium compounds had higher firmness than control.

\section{Ascorbic acid (Vitamin C)}

Vitamin C content of jujube fresh fruits gradually decreased during storage, as the results showed. Zero-day storage showed the highest content of Vitamin C (379.33) compared to the 30- and 40-day storages with the lowest rates of 102.89 and 89 , respectively (Table 1). Ascorbic acid shows sensitivity to destruction when fruits are subjected to adverse postharvest handling and storage conditions (Lee and Kader, 2000). Among the vitamins, ascorbic acid is the least stable and easily destroyed during storage process and is thus very sensitive to degradation (Spinardi, 2005). As an important component of the antioxidative defense mechanism in cells and tissues, vitamin $\mathrm{C}$ acts as a reducing and a chelating agent and has been shown to scavenge free radicals.

Furthermore, analysis of data showed that enhancement of salicylic acid concentrations resulted in a significant increase in Vit. C, so that the highest and lowest contents of Vit. C were observed in $4 \mathrm{mM}$ (222.4) and control (160.93), respectively, as can be seen in Table 1 and Fig. 4A. Salicylic acid as an antioxidant activates ascorbate peroxidase, which, in turns, increases antioxidant ability and ascorbic acid amount in fruits

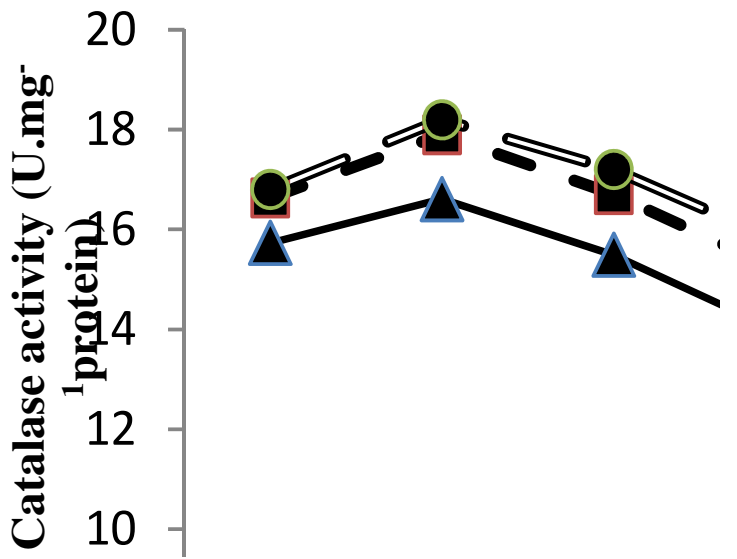

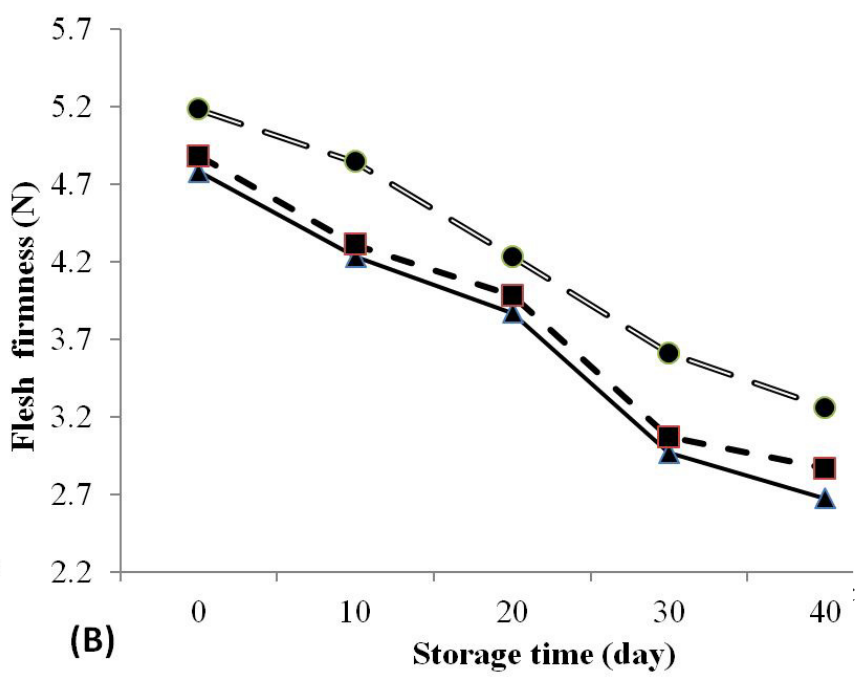

(Dat et al., 1998; Wang et al., 2006). In addition, it has been shown that salicylic acid affects the biosynthesis and action of ethylene (Srivastava and Dwivedi, 2000), prevents vitamin C from being destructed (Wisniewska and Chelcowski, 1999) and acts as an anti-stress power (Elwana and El-Hamahmy, 2009). Reduction in respiration rate in fruits treated with salicylic acid results in the reduction of ethylene biosynthesis and lower activity of ascorbate enzyme by inhibiting ethylene production, thereby maintaining and increasing the level of ascorbic acid (Yahia et al., 2001). Sayyari et al (2009) stated that using salicylic acid at high concentrations $(2 \mathrm{mM})$ maintained ascorbic acid in pomegranate. Application of exogenous salicylic acid on kiwi fruits led to the prevention of softening process, and kept ascorbic acid content and firmness during 5 months of cold storage (Aghdam et al., 2010). Al-Obeed (2012) and Shokrollahfam et al. (2012) also reported that application of salicylic acid prevented the reduction of vitamin $C$ in jujube and plum fruits by delaying the deteriorative oxidation reaction.

With respect to the effect of calcium nitrate on Vit. C, the results showed that the highest content of Vit. $\mathrm{C}$ was obtained in calcium nitrate $2 \%(200.46 \mathrm{mg} / 100 \mathrm{~g} \mathrm{FW})$, while the lowest content was observed in control with $175.89 \mathrm{mg} / 100 \mathrm{~g} \mathrm{FW}$ (Table 1 and Fig. 4B). Shokrollahfam et al. (2012) and Veltman et al. (2000) reported that calcium compounds bind with membrane and increase its stability, therefore, they

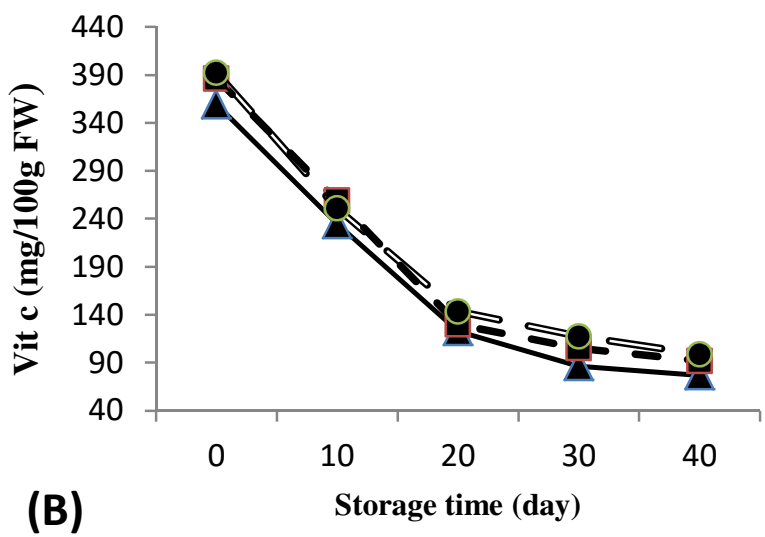

Fig. 4. Effect of salicylic acid and calcium nitrate on vitamin c of jujube fruits; (A) Salicylic acid: (A) Control; (•) Salicylic acid 2

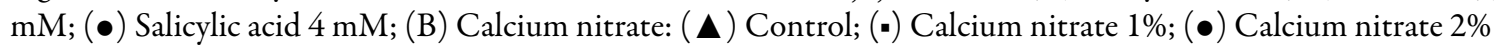


prevent free radicals and reactive oxygen species from connecting to membrane and contribute to the maintenance of the health of biological membranes. Additionally, calcium compounds cause a delay in rapid oxidation of ascorbic acid by increasing the activity of APX. Ruoyi et al. (2005) stated that ascorbic acid content of peaches was stable for fifty-day storage period with the application of $0.5 \% \mathrm{CaCl}_{2}$. Pooviah (1979) reported that the use of calcium chloride (4\%) at harvest time increased ascorbic acid in fruits, and application of calcium before and after harvest improved fruit quality. Al-Obeed (2012) and Shokrolahfam (2012) reported that application of calcium compounds retarded the degradation of Vitamin C content in jujube fruits and plum. The same results on increase of Vitamin C has been reported in apple and kiwi fruit (Paliyath et al., 2009), apple (Sams et al., 1993), pomegranate 'Malas-Yazdi' (Ramezanian et al., 2009), papaya (Selvaraj et al., 1982), strawberry (Shafiee et al., 2010) and tomato (Pila et al., 2010).

\section{Totalphenolics content (TPH)}

Data obtained on the influence of storage intervals on total phenolics content showed that enhancement in duration of shelf life led to the reduction of total phenolic contents, so that the highest phenolic content was obtained at zero-day storage with $3.21 \mathrm{mg}$ GAE/100 g compared to the lowest rate of 1.48 $\mathrm{mg} \mathrm{GAE} / 100 \mathrm{~g}$ at 40-day storage interval (Table 1). Phenolic compounds are the main contributors to functional quality and have a leading role in counteracting reactive oxygen species (ROS), thus minimizing molecular damage. Based on Remorini et al. (2008), decrease in fruit phenolic contents during shelf life is related to the chemical and enzymatic changes occurring during fruit development. Generally, phenolic compounds are reduced during fruit growth and development, which lead to the reduction of astringency. It is suggested that phenolic compounds are incorporated in enzymatic and non-enzymatic reactions during storage, and that may be the reason for lower contents of this chemicals (Sartip and Hajilou, 2015).

Regarding the effect of salicylic acid on total phenolics contents, results showed that an increase in salicylic acid concentration brought about a significant increase in total phenolics content. Based on the results in Table 1 and Fig. 5A, the highest and lowest phenolics contents were observed in SA 2 and $4 \mathrm{mM}$ (2.2 and $2.38 \mathrm{mg} \mathrm{GAE} / 100 \mathrm{~g}$ ) and control (1.91 mg GAE/100 g), respectively. Salicylic acid is a phenol

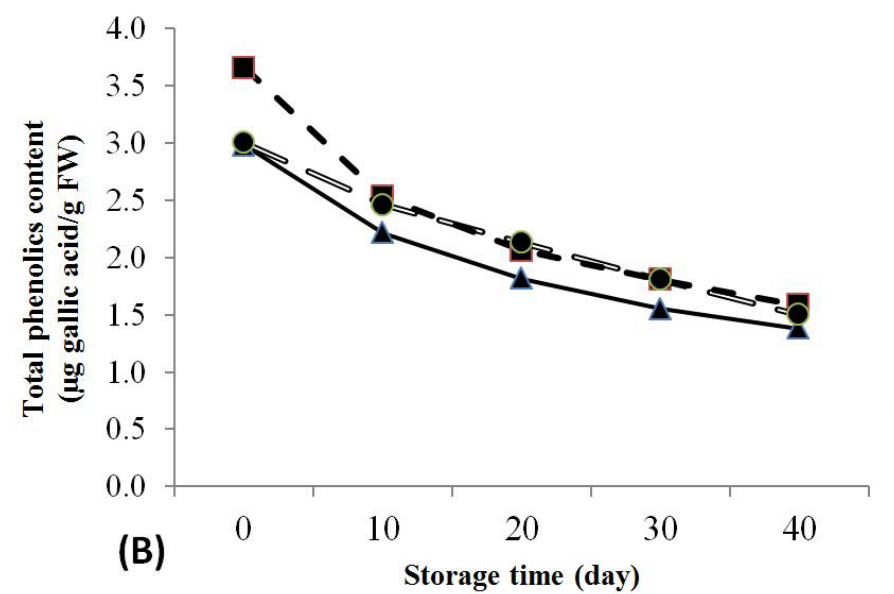

promotive in plants that increases its content via effects on specific enzymes. In addition, salicylic acid has been shown to affect the biosynthesis and action of ethylene (Srivastava and Dwivedi, 2000). In kiwi (Du et al., 2009) and peach (Drogoudi and Tsipouridis, 2007), a significant linear relationship was found between total antioxidant capacity of fruits and total polyphenols, because phenolic compounds are biochemical compounds with high antioxidant activity, so one of the reasons for the increase in antioxidant capacity of fruits treated with salicylic acid can be its effects on fruit phenolic materials.

Data showed that calcium nitrate caused a significant increase in the amount of total phenol. Treatment of calcium nitrate $1 \%$ showed the highest phenol content $(2.32 \mathrm{mg}$ GAE/100 g) in comparison with the control with the lowest rate (1.99 mg GAE/100 g), as the results in Table 1 and Fig. 5B showed. Calcium compounds strengthen cell walls, and maintain and control selective exchange of gas and ion. They also increase the activity of cell wall enzymes, reduce oxygenfree and finally prevent phenol oxidation. The increase in total phenolic in tomato by using calcium compounds was also reported by Pila et al. (2010), which is in agreement with the current results. Plant phenolic compounds have multifunctional properties and can function as singlet oxygen quenchers and scavenge free radicals, thus presence of substantial amounts of phenolic compounds in Chinese jujube indicates that they are a significant source of antioxidants that may provide health promoting advantages to the consumers.

\section{Antioxidant activity ( $A O X)$}

Data in Table 1 showed that there was significant difference among different periods of fruit storage. Increase in shelf life duration led to the reduction of antioxidant activity, so that the highest value was obtained at zero-day storage (97.7 $\mathrm{mmol}$ Trolox/g) and the lowest rates were due to 30- and 40day storage intervals ( 57.3 and $52.8 \mathrm{mmol}$ Trolox/g). The parameter shows the existence of efficient oxygen radical scavengers, such as vitamin $\mathrm{C}$ and phenolic compounds and their synergistic and/or antagonistic effects. Antioxidant activity varies according to the stage of growth and fruit ripening. Possible reasons for the decrease in total antioxidant in fruits during storage can be chemical changes (enzymatic and non-enzymatic reactions) leading to the destruction of the walls and cell membranes, creation of reactive oxygen and free radicals, and participation of antioxidants themselves in cellular metabolism and their consumption during storage (Sánchez Moreno et al., 1998; Remorini et al., 2008).

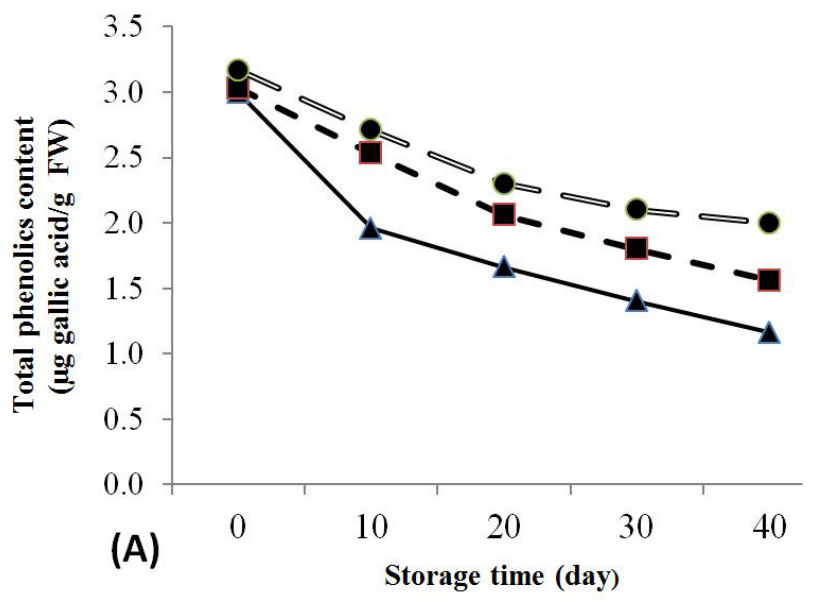

Fig. 5. Effect of salicylic acid and calcium nitrate on total phenolics content of jujube fruits; (A) Salicylic acid: ( $\mathbf{\Delta})$ Control; (•)

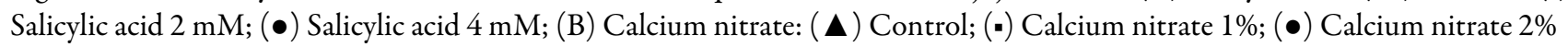


144

Antioxidant activity was also affected by salicylic acid, as the results showed. As can be seen in Table 1 and Fig. 6 A, the highest and lowest rates of antioxidant activity were observed in treatment containing $4 \mathrm{mM}$ salicylic acid $(76.76 \mathrm{mmol}$ Trolox/g) and control (65.93 mmol Trolox/g), respectively. The current results were in agreement with the findings reported on strawberry (Shafiee et al., 2010), pear (Cao et al., 2006) and apricot (Ardakani, 2013).

Salicylic acid increases antioxidant activity through the expression of oxidase gene, removes toxic effects of free radicals and protects plant cell tensions against all kinds of stresses (Turnham, 1990; Zhang and Schmidt, 1999). Pila et al. (2010) stated that salicylic acid increased the activity of phenylalanine ammonia-lyase enzyme, a key enzyme in the phenylpropanoids metabolism, enhanced the synthesis and accumulation of important phenolic compounds with antioxidant properties, and finally increased tissue resistance to living and non-living stressors.

Results obtained from Ca application showed that calcium nitrate increased the antioxidant activity, so that the highest and lowest rates were observed in calcium nitrate $2 \%(75.13$ mmol Trolox/g) and control (67.26 mmol Trolox/g), respectively (Table 1 and Fig. $6 \mathrm{~B}$ ). An increase in reactive oxygen species and free radicals (oxidative metabolism) in fruit ripening stages damages cell membrane and increases senescence. Therefore any treatment that reduces the amount of damage to the cell membrane or cell wall strength such as the use of calcium compounds can reduce the amount of reactive oxygen species and free radicals by control and maintenance of

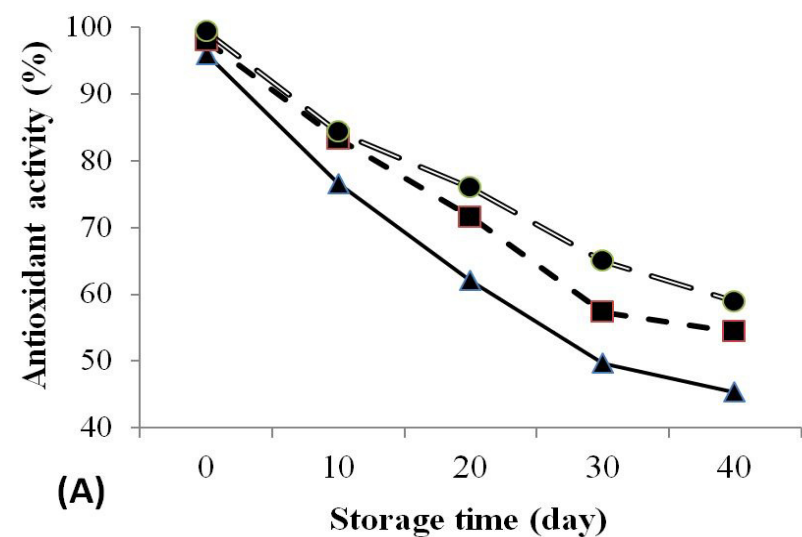

gas exchange and increase of cell wall enzyme activity. Paliyath et al. (2009) reported that calcium stimulates and increases tissue resistance to damage by increasing antioxidant activity; therefore use of calcium compounds before and after harvest fruits and vegetables has positive effects on antioxidant activity.

\section{Catalase activity (CAT)}

Based on the results obtained, different periods of fruit storage showed significant differences from each other. An increase in the duration of storage led to the reduction of catalase activity, so that 10-day storage duration showed the highest catalase activity (17.57 U. mg- protein), a $4.63 \mathrm{U} . \mathrm{mg}^{\circ}$ ${ }^{1}$ protein increase compared to 40-days storage with the lowest rate (Table 1). Reduction found in catalase activity during higher storage duration is in line with the results reported in some other fruits such as peach (Han et al., 2002), plum (Perez et al., 2003), cherry (Martinez et al., 2006) and banana (Srivastava and Dwivedi, 2000). Catalase is one of the important enzymes that can protect cells from oxidative damage by scavenging reactive oxygen species (ROS) (Scandalios, 1993; Lee and Lee, 2000). ROS accumulation results in oxidative injury, which accelerates the progression of senescence and different senescence-associated disorders (Stadtman, 1992). Studies demonstrated that ROS led to oxidative damage of mitochondria and accelerated senescence processes in peach fruit (Qin et al., 2009). Increased ROS and free radicals due to the increased oxidative metabolism during the ripening process of fruits can cause damage to cell membranes and increase the speed of senescence.

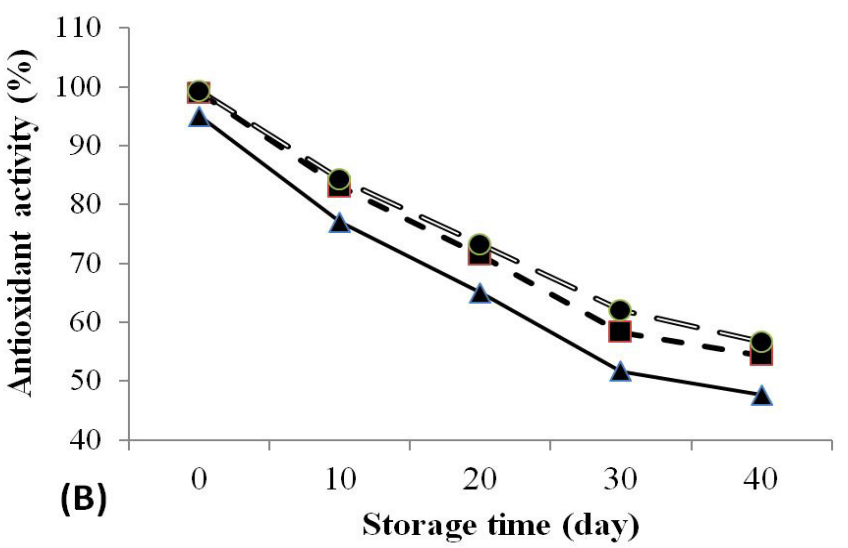

Fig. 6. Effect of salicylic acid and calcium nitrate on antioxidant activity of jujube fruits; (A)Salicylic acid: ( $\mathbf{\Delta}$ ) Control; (•)

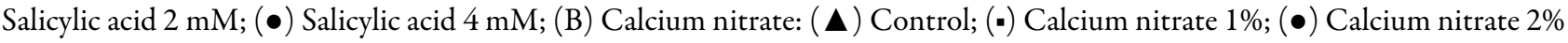
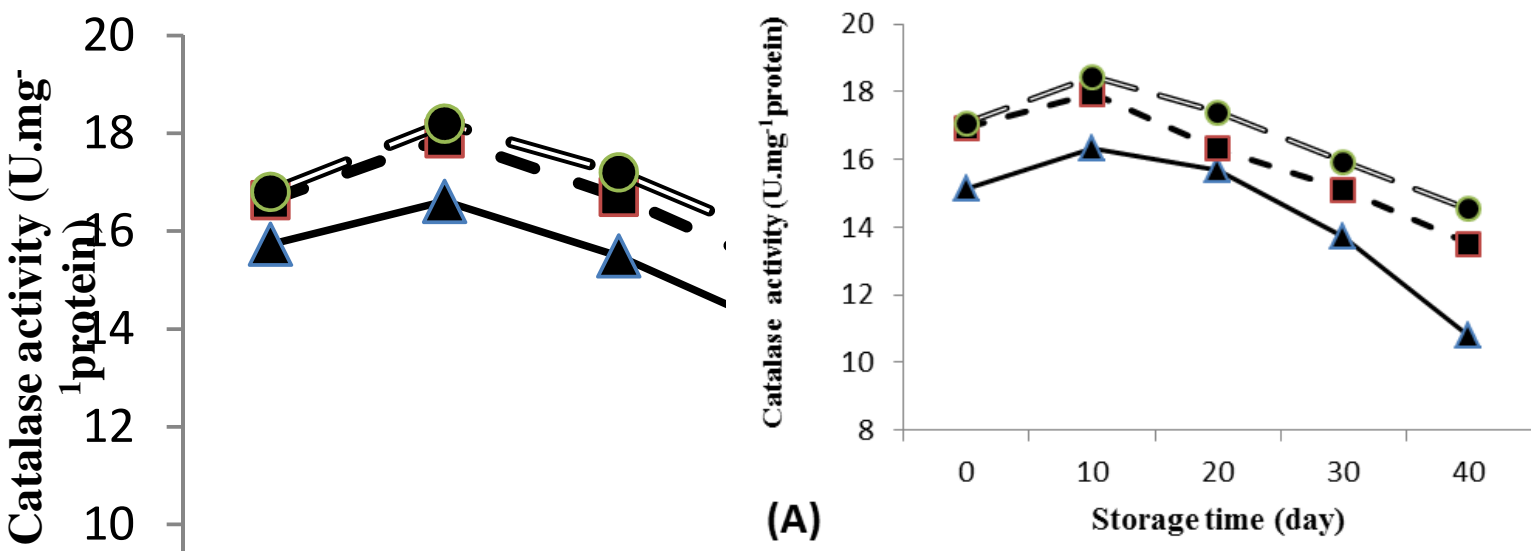

Fig. 7. Effect of salicylic acid and calcium nitrate on catalase activity of jujube fruits; (A)Salicylic acid: ( $\Delta$ ) Control; (•) Salicylic

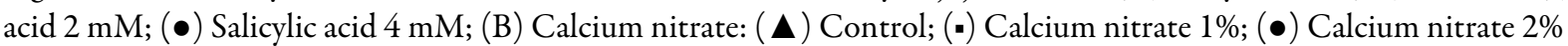


The results in Table 1 and Fig. 7A showed that increase in salicylic acid concentration significantly increased CAT activity, so that the highest and the lowest catalase activity was observed in $4 \mathrm{mM}$ (16.67 U. $\mathrm{mg}^{-1}$ protein) and control (14.33 $\mathrm{U} . \mathrm{mg}^{-1}$ protein), respectively. The increase found in catalase activity by using salicylic acid was also reported by Srivastava and Dwivedi (2000) in bananas, Zainuri and Terry (2001) in mango and Han et al. (2002) in peach. The effect of salicylic acid can be associated to its ability in the increase in the activity of antioxidant enzymes, which maintain the nutritional value of vegetables and fruits by preventing the detrimental effects of free radicals (Jing et al., 2008). By expressing the alternative oxidase genes, salicylic acid increases the activity of antioxidant enzymes, and antioxidants together reduce the toxicity of free radicals and protect plant cells against different kinds of stresses (Hogg et al., 1993; Asghari and Aghdam, 2010).

Data indicated that calcium nitrate increased catalase activity. The highest activity was observed in treatment containing calcium nitrate $2 \%\left(16.3 \mathrm{U} \cdot \mathrm{mg}^{-1}\right.$ protein) and the lowest was seen in control (14.7 U. mg ${ }^{-1}$ protein), as the results in Table 1 and Fig. 7 B showed. According to John (1987), calcium compounds improve rigidity of cell wall and prevent enzymes such as polygalacturonase and catalase from reaching their active sites, thereby retarding tissue softening and delaying ripening. Lester and Grusak (2004) reported that the use of calcium compounds maintained the solidity of cell membrane by binding with phospholipids and proteins and caused strength and tightness of the skin and flesh fruit. Strengthening cell wall results in the increase in the activity of antioxidant enzymes, reduces ROS and delays senescence. Furthermore, Zhang and $\mathrm{Li}$ (2014) reported that any factor affecting the strength of the cell membrane can control active oxygen metabolism and $\mathrm{H}_{2} \mathrm{O}_{2}$ by the activation of antioxidant enzymes (Cat, Sod).

\section{Conclusions}

The results of this study showed the positive effect of all the sprayed agro-chemicals on the quality of jujube fresh fruit. Based on the results, application of calcium nitrate and salicylic acid improved firmness, Vitamin C content, titratable acidity, total phenolic content, antioxidant activity and catalase enzyme and reduced total soluble solids. Finally, the obtained results suggested that application of salicylic acid at the concentration of $4 \mathrm{mM}$ and calcium nitrate $2 \%$ can be a feasible and easy technique for maintaining the fruit quality and extending postharvest life of jujube fresh fruit.

\section{References}

Aguayo E, Jansasithorn R, Kader AA (2006). Combined effects of 1methylcyclopropene, calcium chloride dip, and/or atmospheric modification on quality changes in fresh-cut strawberries. Postharvest Biology and Technology 40(3):269-278.

Aghdam MS, Motallebiazar A, Mostofi Y, Moghaddam JF, Ghasemnezhad $\mathrm{M}$ (2010). Effects of MeSA vapor treatment on the postharvest quality of'Hayward' kiwifruit. Acta Horticulturae 877:743-748.

Al-Obeed RS (2010). Improving fruit quality, marketability and storagability of Barhee date palm. World Applied Sciences Journal 9(6):630-637.
Al-Obeed RS (2012). Jujube post-harvest fruit quality and storagability in response to agro-chemicals preharvest application. African Journal of Agricultural Research 7(36):5099-5107.

Asghari M, Aghdam MS (2010). Impact of salicylic acid on post-harvest physiology of horticultural crops. Trends in Food Science and Technology21(10):502-509.

Ardakani A, Davarynejad GH, Azizi M (2013). Impact of pre-harvest spry salicylic acid application on storability, postharvest quality and antioxidant activity apricot (Prunus armeniaca L). Journal of Horticulture Science 26(4):448-459.

Boora RS, Bal JS (2008). Status of Indian jujube (Ziziphus mauritiana) in irrigated sub-humid and arid irrigated eco-system of Punjab. In: 1st International Jujube Symposium. Baoding, China pp 21-25.

Brand-Williams W, Cuvelier ME, Berset CLWT (1995). Use of a free radical method to evaluate antioxidant activity. LWT - Food Science and Technology 28(1):25-30.

Cao J, Yan J, Zhao Y, Jiang W (2013). Effects of postharvest salicylic acid dipping on Alternaria rot and disease resistance of jujube fruit during storage. Journal of the Science of Food and Agriculture 93:3252-3258

Cao J, Zeng K, Jiang W (2006). Enhancement of postharvest disease resistance in Ya Li pear (Pyrus bretschneideri) fruit by salicylic acid sprays on the trees during fruit growth. European Journal of Plant Pathology 114(4):363-370.

Chen F, Liu H, Yang H, Lai S, Cheng X, Xin Y, Bu G (2011). Quality attributes and cell wall properties of strawberries (Fragaria annanassa) under calcium chloride treatment. Food Chemistry 126(2):450-459.

Cheour F, Willemot C, Arul J, Makhlouf J, Desjardins Y (1991). Postharvest response of two strawberry cultivars to foliar application of $\mathrm{CaCl}_{2}$. HortScience 26(9):1186-1188.

Crisosto CH, Garner D, Crisosto GM, Bowerman E (2004). Increasing 'Blackamber' plum (Prunus salicina) consumer acceptance. Postharvest Biology and Technology34(3):237-244.

Dat JF, Foyer CH, Scott IM (1998). Changes in salicylic acid and antioxidants during induced thermotolerance in mustard seedlings. Plant Physiology 118(4):1455-1461.

Du G, Li M, Ma F, Liang D (2009). Antioxidant capacity and the relationship with polyphenol and vitamin $\mathrm{C}$ in Actinidia fruits. Food Chemistry 113(2):557-562.

Drogoudi PD, Tsipouridis CG (2007). Effects of cultivar and rootstock on the antioxidant content and physical characters of clingstone peaches. Scientia Horticulturae 115(1):3439.

Ecevit FM, Şan B, Dilmaç Ünal T, Hallaç Türk F, Yıldırım AN, Polat M, Yildurm F (2008). Selection of superior Ber (Ziziphus jujuba L.) genotypes in Civril region. Tarmm Bilimleri Dergisi 14(1):51-56.

Elwan MWM, El-Hamahmy MA M (2009). Improved productivity and quality associated with salicylic acid application in greenhouse pepper. ScientiaHorticulturae 122(4):521-526.

Ercisli S, Orhan E, Ozdemir O, Sengul M (2007). The genotypic effects on the chemical composition and antioxidant activity of sea buckthorn (Hippophae rhamnoides L.) berries grown in Turkey. Scientia Horticulturae 115(1):27-33.

Fischer RL, Bennett AB (1991). Role of cell wall hydrolases in fruit ripening. Annual Review of Plant Biology 42(1):675-703. 
146

Gao QH, Wu CS, Wang M (2013). The Jujube (Ziziphus jujuba Mill.) fruit: A review of current knowledge of fruit composition and health benefits. Journal of Agricultural and Food Chemistry 61(14):33513363.

Gao QH, Wu PT, Liu JR, Wu CS, Parry JW, Wang M (2011). Physicochemical properties and antioxidant capacity of different jujube (Ziziphus jujuba Mill.) cultivars grown in loess plateau of China. Scientia Horticulturae 130(1):67-72.

Han T, Li LP (1997). Physiological effect of salicylic acid on storage of apple in short period. Plant Physiology Communications 33:347-348.

Han T, Wang Y,Li L, Ge X(2003). Effect of exogenous salicylic acid on post harvest physiology of peaches. Acta Horticulturae 628:583-589.

Hernández-Muñoz P, Almenar E, Ocio MJ, Gavara R (2006). Effect of calcium dips and chitosan coatings on postharvest life of strawberries (Fragaria $\times$ ananassa). Postharvest Biology and Technology 39(3):247253.

Hogg N, Kalyanaraman B, Joseph J, Struck A, Parthasarathy S (1993). Inhibition of low density lipoprotein oxidation by nitric oxide Potential role in atherogenesis. FEBS Letters 334(2):170-174.

Hubbard NL, Pharr DM, Huber SC (1991). Sucrose phosphate synthase and other sucrose metabolizing enzymes in fruits of various species. Physiologia Plantarum 82(2):191-196.

JiangW, Sheng Q, Jiang Y,Zhou X(2004). Effects of 1-methylcyclopropene and gibberellic acid on ripening of Chinese jujube (Zizyphus jujuba) in relation to quality. Journal of the Science of Food and Agriculture 84(1):31-35.

Jing-Hua Y, Yuan G, Yan-Man L, Xiao-Hua Q,Zhang MF (2008). Salicylic acid-induced enhancement of cold tolerance through activation of antioxidative capacity in watermelon. Scientia Horticulturae 118(3):200-205.

Ji X, Peng Q, Yuan Y, Shen J, Xie X, Wang M (2017). Isolation, structures and bioactivities of the polysaccharides from jujube fruit (Ziziphusjujuba Mill.): A review. Food Chemistry 227:349-357.

John MA (1987). Fruit Softening. In: Mangoes - a review. Prinsley RT, TuckerG(Eds). Commonwealth Science Council,London pp 98-106.

Khan W, Prithiviraj B, Smith DL (2003). Photosynthetic responses of corn and soybean to foliar application of salicylates. Journal of Plant Physiology 160(5):485-492.

Kirkbride JH, Wiersema JH, Turland NJ (2006). Proposal to converse the name Ziziphusjujube against $Z$. zizyphus (Rhamnaceae). Taxon 5:10271052.

Kokabi S, Tabatabaei SJ (2011). Effect of different K:Ca ratios on yield and quality of Galia (Cucumismelo var. reticulatus l. naud.cv. Galia) grown in hydroponics. Journal of HorticultureScience 25(2):178-184.

Lara I, Garcia P, Vendrell M (2004). Modifications in cell wall composition after cold storage of calcium-treated strawberry (Fragaria $\times$ ananassa Duch.) fruit. Postharvest Biology and Technology 34(3):331-339.

Lee DH, Lee CB (2000). Chilling stress-induced changes of antioxidant enzymes in the leaves of cucumber: in gel enzyme activity assays. Plant Science 159(1):75-85.

Lee SK, Kader AA (2000). Preharvest and postharvest factors influencing vitamin $\mathrm{C}$ content of horticultural crops. Postharvest Biology and Technology 20(3):207-220.
Leslie C A, Romarini RJ (1988). Inhibition of ethylene biosynthesis by salicylic acid. Plant Physiology 88(3):833-837.

Lester G E, Grusak MA (2004). Field application of chelated calcium: postharvest effects on cantaloupe and honeydew fruit quality. HortTechnology 14(1):29-38.

Li JW, Fan LP, Ding SD, Ding XL (2007). Nutritional composition of five cultivars ofChinese jujube. Food Chemistry 103(2):454-460.

Liu MJ,ZhaoZH (2009). Germplasm resources and production of jujube in China. Acta Horticulturae 840:25-32.

Manganaris GA, Vasilakakis M, Diamantidis G, Mignani I (2007). The effect of postharvest calcium application on tissue calcium concentration, quality attributes, incidence of flesh browning and cell wall physicochemical aspects of peach fruits. Food Chemistry 100(4):1385-1392.

Marschner H (2011). Marschner's mineral nutrition of higher plants. Academic Press.

Martínez-Romero D, Alburquerque N, Valverde JM, Guillén F, Castillo S, Valero D, Serrano M (2006). Postharvest sweet cherry quality and safety maintenance by Aloe vera treatment: a new edible coating. Postharvest Biology and Technology39(1):93-100.

Marzouk HA, Kassem HA (2011). Improving yield, quality, and shelflife of Thompson seedless grapevine by preharvest foliar applications. Scientia Horticulturae 130(2):425-430.

Nunes MCN, Brecht JK, Morais AMMB, Sargent SA (1995). Physical and chemical quality characteristics of strawberries after storage are reduced by a short delay to cooling. Postharvest Biology and Technology 6(1):1728.

Paliyath G, Murr, DP, Handa AK, Lurie S (2009). Postharvest biology and technology of fruits, vegetables and flowers. John Wiley \& Sons Press (2thEd), USA.

Perez-Gago MB, Rojas C, Del Rio MA (2003). Effect of hydroxypropyl methylcellulose-lipid edible composite coatings on plum (cv. Autumn giant) quality duringstorage. Journal of Food Science 68(3):879-883.

Pila N, Gol NB, Rao TR (2010). Effect of post harvest treatments on physicochemical characteristics and shelf life of tomato (Lycopersicon esculentum Mill.) fruits during storage. American-Eurasian Journal of Agricultural and Environmental 9(5):470-479.

Poovaiah BW (1979). Role of calcium in ripening and senescence. Communications in Soil Science and Plant Analysis 10(2):83-88.

Prasanna V, Prabha TN, Tharanathan RN (2007). Fruit ripening phenomena-an overview. Critical Reviews in Food Science and Nutrition 47(1):1-19.

Qin G, Meng X, Wang Q, Tian S (2009). Oxidative damage of mitochondrial proteins contributes to fruit senescence: a redox proteomics analysis. Journal of Proteome Research 8(5):449-462.

Rao TR, Gol NB, Shah KK (2011). Effect of postharvest treatments and storage temperatures on the quality and shelf life of sweet pepper (Capsicum annum L.). Scientia Horticulturae 132:18-26.

Rizk-Alla MS, Meshreki AM (2006). Effect of pre-harvest application of $\mathrm{GA}_{3}$, potassium and glucose on fruit quality and storability of Crimson Seedless cultivar. Egyptian Journal of Basic and Applied Sciences 20(6A):210-238.

Ramezanian A, Rahemi M, Vazifehshenas MR (2009). Effects of foliar application of calcium chloride and urea on quantitative and qualitative 
characteristics of pomegranate fruits. Scientia Horticulturae 121(2):171175.

Remorini D, Tavarini S, Deg'Innocenti E, Loreti F, Massai R, Guidi L (2008). Effect of rootstocks and harvesting time on the nutritional quality of peel and flesh of peach fruits. Food Chemistry 110(2):361367.

Reynolds T, Dweck AC (1999). Aloe vera leafgel: a review update. Journal of Ethnopharmacology 68(1):3-37.

Ruoyi K, Zhifang Y, Zhaoxin L (2005). Effect of coating and intermittent warming on enzymes, soluble pectin substances and ascorbic acid of Prunus persica (cv. Zhonghuashoutao) during refrigerated storage. Food Research International 38(3):331-336.

Sams CE, Conway WS, Abbott JA, Lewis RJ, Ben-Shalom N (1993). Firmness and decay of apples following postharvest pressure infiltration of calcium and heat treatment. Journal of the American Society for Horticultural Science 118(5):623-627.

Sánchez-Moreno C, Larrauri JA, Saura-Calixto F (1998). A procedure to measure the antiradical efficiency of polyphenols. Journal of the Science of Food and Agriculture 76(2):270-276.

Sartip G, Hajilou J (2015). Effect of preharvest application salicylic acid on physicochemical characteristics of apricot (Prunus armeniaca $\mathrm{l}$.) fruits cv. 'Shamlou' during storage. Journal of Crops Improvement 17(1):81-91.

Sayyari M, Babalar M, Kalantari S, Serrano M, Valero D (2009). Effect of salicylic acid treatment on reducing chilling injury in stored pomegranates. Postharvest Biology and Technology 53(3):152-154.

Scandalios JG (1993). Oxygen stress and superoxide dismutases. Plant Physiology 101(1):7-12.

Selvaraj Y, Pal DK, Subramanyam MD, Iyer CPA (1982). Changes in the chemical composition of four cultivars of papaya (Carica papaya L.) during growth and development. Journal of Horticultural Science 57(1):135-143.

Serrano M, Martínez-Romero D, Castillo S, Guillén F, Valero D (2004). Role of calcium and heat treatments in alleviating physiological changes induced by mechanical damage in plum. Postharvest Biology and Technology 34(2):155-167.

Shafiee M, Taghavi TS, Babalar M (2010). Addition of salicylic acid to nutrient solution combined with postharvest treatments (hot water, salicylic acid, and calcium dipping) improved postharvest fruit quality of strawberry. Scientia Horticulturae 124(1):40-45.

Shamili M, Hajiani I (2012). The influence of calcium treatment on Ziziphus spp. fruit quality. Abstracts of 7th International Postharvest Symposium 25-29 June, 2012. Putra World Trade Centre (PWTC), Kuala Lumpur,Malaysia.

Shokrollahfam S, Hajilou J, Zare F, Tabatabaei SJ, Naghshibandhasani R (2012). Effects of calcium chloride and salicylic acid on quality traits and storage life of plum cultivar.Journal of Food Research 22(1):75-76.

Slinkard K, Singleton VL (1977). Total phenol analysis: automation and comparison with manual methods. American Journal of Enology and Viticulture 28(1):49-55.

Spinardi AM (2005). Effect of harvest date and storage on antioxidant systems in pears. Acta Horticulturae 682:135-140.
Srivastava MK, Dwivedi UN (2000). Delayed ripening of banana fruit by salicylic acid. Plant Science 158(1):87-96.

Stadtman ER(1992). Protein oxidation and aging. Science 257(5074):12201224.

Sudha R, Amutha R, Muthulaksmi S, Baby Rani W, Indira K, Mareeswari P (2007). Influence of pre and post-harvest chemical treatments on physical characteristics of sapota (Achras sapota L.) var. PKM 1. Research Journal of Agriculture and Biological Sciences 3(5):450-452.

Thurnham DI (1990). Antioxidants and prooxidants in malnourished populations. Proceedings of the Nutrition Society 49(02):247-259.

Veltman RH, Kho RM, Van Schaik ACR, Sanders MG, Oosterhaven J (2000). Ascorbic acid and tissue browning in pears (Pyrus communis L. cvs Rocha and Conference) under controlled atmosphere conditions. Postharvest Biology and Technology 19(2):129-137.

Vicente A R, Pineda C, Lemoine L, Civello PM, Martinez GA, Chaves AR (2005). UV-C treatments reduce decay, retain quality and alleviate chilling injury in pepper. Postharvest Biology and Technology 35(1):6978.

Wang L, Chen S, Kong W, Li S, Archbold DD (2006). Salicylic acid pretreatment alleviates chilling injury and affects the antioxidant system and heat shock proteins of peaches during cold storage. Postharvest Biology and Technology 41(3):244251.

Wang YS, Tian SP, Xu Y (2005). Effects of high oxygen concentration on pro-and anti-oxidant enzymes in peach fruits during postharvest periods. Food Chemistry 91(1):99-104.

Wu CS, Gao QH, Guo XD, Yu JG, Wang M (2012). Effect of ripening stage on physicochemical properties and antioxidant profiles of a promising table fruit 'pear-jujube' (Zizyphus jujuba Mill.). Scientia Horticulturae 148:177-184.

Yahia EM, Contreras-Padilla M, Gonzalez-Aguilar G (2001). Ascorbic acid content in relation to ascorbic acid oxidase activity and polyamine content in tomato and bell pepper fruits during development, maturation and senescence. LWT - Food Science and Technology 34(7):452-457.

Zainuri JL, Terry L (2001). Effects of phosphonate and salicylic acid treatments on anthracnose disease development and ripening of 'Kensington Pride' mango fruit. Australian Journal of Experimental Agriculture 41:805-813.

Zhao Al, Li DK, Wang YK, Sui CL, Du XM (2008). Study on the contents of triterpenic acid and flavonoids in jujubes of different cultivars in different growing periods at different positions. In: 1st International JujubeSymposium, Baoding, Chinapp 21-25.

Zhang X, Schmidt RE (1999). Biostimulating turfgrasses. Grounds Maintenance 34:1415.

Zhang Y, Chen K, Zhang S, Ferguson I (2003). The role of salicylic acid in postharvest ripening of kivifruit. Postharvest Biology and Technology 28(1):67-74.

Zhang S, Li N (2014). Effects of carbon monoxide on quality, nutrients and antioxidant activity of post-harvest jujube.Journal of the Science of Food and Agriculture 94(5):1013-1019. 